\title{
Ontogeny of $\beta$-Adrenergic Receptors in the Rat Lung: Effects of Hypothyroidism
}

\author{
JEFFREY A. WHITSETT, ${ }^{(33)}$ CHARLOTTE DAROVEC-BECKERMAN, JENNIFER POLLINGER, AND \\ JOHN J. MOORE, JR. \\ Children's Hospital Research Foundation, Newborn Division of Pediatrics [J. A. W.], University of Cincinnati College \\ of Medicine, Cincinnati, Ohio, USA
}

\begin{abstract}
Summary
$\beta$-Adrenergic receptors were identified in membrane fractions of rat lung with the $\beta$-adrenergic antagonists $(-)-\left[{ }^{3} \mathrm{H}\right]$-dihydroalprenolol $\left((-)-\left.\right|^{3} H \mid D H A\right)$ and $( \pm)-\left.\right|^{125} I \mid$-iodohydroxybenzylpindolol $\left(( \pm)-\left.\right|^{125}[\mid H Y P)\right.$. Binding capacity $\left(B_{\max }\right)$ for $\left.(-)-\left.\right|^{3} H\right] D H A$ increased progressively from $46 \pm 7$ on day 18 of gestation to 510 \pm 70 femtomoles $\bullet \mathrm{mg}^{-1}$ protein (mean \pm S.D.) on postnatal day 28 , at which time adult $B_{\max }$ was attained. An increase in $(-)-\left[{ }^{3} \mathbf{H}\right]$ DHA binding capacity of the lung was observed between postnatal days 15 and 28 , during the known period of increased thyroid gland secretory activity, serum triiodothyronine (T3), and thyroxine (T4) concentrations in the rat. We therefore studied lung $\beta$ adrenergic receptors in rat pups made hypothyroid with propylthiouracil (PTU) (in utero and postnatally) compared to normal agematched control pups and to euthyroid pups which were treated with PTU but were also injected daily with thyroxine (T4-treated). Hypothyroid pups grew nearly normally until postnatal day 15 but grew poorly thereafter; by day 28 somatic and lung weight, lung DNA, and protein were markedly decreased in hypothyroid pups as compared to controls. Pulmonary $\beta$-adrenergic receptors were similar in hypothyroid pups and controls on day 15 , but were markedly decreased in hypothyroid pups on day 28 (294 \pm 57 versus $489 \pm 82$ femtomoles $\bullet \mathrm{mg}^{-1}$ protein in T4 treated euthyroid controls). Treatment of the hypothyroid pups with T4 on day 25 significantly increased lung $\beta$-adrenergic receptors to near normal concentrations by day 28 . We conclude that thyroid hormones or thyroid dependent factors enhance pulmonary $\boldsymbol{\beta}$-adrenergic receptor synthesis and that thyroid hormone is required for the normal postnatal maturation of the $\beta$-adrenergic receptor system in the rat lung.
\end{abstract}

\section{Speculation}

Thyroid hormone or thyroid hormone dependent factors are required for the normal postnatal growth and maturation of the rat lung. Pulmonary $\beta$-adrenergic receptors increase markedly during the perinatal period in the rat and their normal postnatal development is thyroid hormone dependent. Because the timing of increased thyroid gland activity varies among species, occurring earlier in the human than in the rat, the possible effects of thyroid hormone on pulmonary maturation in the human might also occur at an earlier time in perinatal life. Finally, it is speculated that the ontogenic increases in pulmonary $\beta$-adrenergic receptors are also associated with developmental changes in catecholamine mediated cellular responses of specific pulmonary cells.

Catecholamines are mediators of surfactant release (7) and smooth muscle tone in the mammalian lung. These effects are presumably the result of the interactions of adrenergic agonists with $\beta$-adrenergic receptors present on the plasma membranes of various pulmonary cells, resulting in the stimulation of adenylate cyclase thus increasing intracellular $3^{\prime}, 5^{\prime}$ cyclic adenosine mono- phosphate (cAMP) $(2,17)$. Studies from this laboratory have recently demonstrated that pulmonary $\beta$-adrenergic receptors in the rat and rabbit increase dramatically during late gestation and during the suckling period, reaching adult levels by 28 days of postnatal age (26). Cheng et al. (5) have also recently demonstrated the role of corticosteroids on the prenatal increase in pulmonary $\beta$-adrenergic receptors. In preliminary studies of the postnatal maturation of the $\beta$-adrenergic receptor in rat lung, we noted that a thyroid dependent increase in $\beta$-adrenergic receptors occurred between postnatal days 14 and 28 , during the period of increased thyroid gland activity and increased serum triiodothyronine (T3) and thyroxine (T4) concentrations which occurs late in neonatal life in this species as compared to the human $(8,26,27)$. Several studies have also demonstrated that thyroid hormones or the thyroid analog 3,5-dimethyl-3'-isopropyl-1-thyronine (DIMIT) may enhance pulmonary maturation in the late fetal period in mammals $(1,23,32)$. Thyroxine or DIMIT enhances phospholipid synthesis and the morphologic and biochemical maturation of Type II pneumocyte in the fetal rabbit. A relationship between delayed lung maturation (hyaline membrane disease) and low serum T4 has also been demonstrated in humans $(1,6,19,23,32)$. Although the role of thyroid hormone in pulmonary maturation in the perinatal period has been suggested, the possible role of thyroid hormone on the postnatal development of $\beta$-adrenergic receptors and their characteristics in the lung has not been subjected to such scrutiny.

A relationship between thyroid activity and $\beta$-adrenergic receptors has also been demonstrated previously; triiodothyronine (T3) in vitro increased $\beta$-adrenergic receptors in isolated rat myocytes (25). Likewise, rats made hyperthyroid in vivo had increased $\beta$ adrenergic receptors present in myocardial homogenates (30). In addition to such direct effects of thyroid hormone on $\beta$-adrenergic systems in the mature animal, thyroid hormone exerts potent maturational effects on numerous organs including brain, liver and the lung $(9,10)$. The present study was therefore designed to assess the effects of hypothyroidism on the postnatal growth of the rat lung and to further clarify the effects of hypothyroidism and thyroxine treatment on the known developmental increase in pulmonary $\beta$-adrenergic receptors.

\section{MATERIALS AND METHODS}

Animals. Timed-bred Wistar rats were purchased from Charles River Corp. Dams were fed standard rat chow and maintained at $24^{\circ} \mathrm{C}$ in a $12 \mathrm{~h}$ light-dark cycle. Three groups of animals were maintained in individual cages and treated as follows: Group Ihypothyroid rats were treated by adding $0.05 \%$ propylthiouracil (PTU) to their drinking water from day 16 of gestation until the time of sacrifice. Pups were nursed in litters of less than 10 pups until sacrifice. Group II-euthyroid control rats were maintained on $0.05 \%$ PTU from day 16 of gestation. The pups were injected subcutaneously each day with thyroxine (T4) in $0.9 \% \mathrm{NaCl}, 0.1$ $\mathrm{mM} \mathrm{NaOH}$ as follows: $0.05 \mu \mathrm{g}$ daily on postnatal days $1-5,0.10$ 
$\mu \mathrm{g}$ on days $6-14$ and $0.30 \mu \mathrm{g}$ on days $15-28$, as described by Hamburgh et al. (11). Animals received their last T4 injection 24 h before sacrifice. Group III-untreated control rats were maintained with the dam in litters of less than 10. Sham injection with $0.1 \mathrm{ml}$ saline did not alter $\beta$-adrenergic receptors in preliminary experiments.

Adult female Wistar rats (250-270 g) were also maintained on $0.05 \%$ PTU for 6 wk and compared with normal female controls of the same weight. Serum thyroxine was determined by a standard clinical radioimmunoassay in serum from individual animals collected after decapitation. Limits of detection were $1.0 \mu \mathrm{g} / \mathrm{dl}$ for T4.

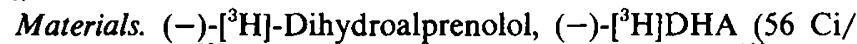
mmole); ( \pm )- $\left[{ }^{125} \mathrm{I}\right]$-iodohydroxybenzylpindolol, $( \pm)-\left[{ }^{125} \mathrm{I}\right] \mathrm{HYP}$ $(2200 \mathrm{Ci} / \mathrm{mmole}) ;\left[\alpha^{32} \mathrm{P}\right] \mathrm{ATP}$; and $\left[{ }^{3} \mathrm{H}\right]$ cAMP were purchased from New England Nuclear Corp. (Boston, MA). (-)-Norepinephrine$\mathrm{HCl}$, (-)-isoproterenol bitartrate, (+)-isoproterenol bitartrate, (-)-epinephrine bitartrate, calf thymus DNA, (-)-thyroxine, propylthiouracil and other reagents were purchased from Sigma Chemical Co. (St. Louis, MO). (-)-Propranolol, (-)-alprenolol, and (+)-propranolol were obtained from Ayerst Laboratories (Rouses Point, NY). (-)-Phentolamine mesylate was obtained from Ciba Pharmaceuticals Co. (Summit, NJ). Zinterol hydrochloride was the generous gift of the Mead-Johnson Corp.

Membrane preparation. Animals were weighed and sacrificed by decapitation. The lungs from individual animals were dissected with care to remove tracheal and hilar structures, diced, and placed in iced buffer containing $250 \mathrm{mM}$ sucrose, $1 \mathrm{mM}$ EGTA, and $5 \mathrm{mM}$ Tris- $\mathrm{HCl}, \mathrm{pH}$ 7.2. Lung samples from entire litters were pooled to obtain prenatal samples and two pups were pooled for each preparation on day 5 because of the paucity of material. Thereafter lungs were obtained from individual animals. The washed tissue was homogenized with a Tekmar Tissuemizer (Tekmar Co., Cincinnati, $\mathrm{OH}$ ) in 20 volumes of the sucrose buffer per wet weight of lung tissue at $4^{\circ} \mathrm{C}$ with three 5 -sec bursts at high setting. Samples of this homogenate were taken for DNA and protein determinations $(4,14)$. The remaining homogenate was poured through four layers of gauze and centrifuged at $3000 \mathrm{Xg}$ for $5 \mathrm{~min}$. The supernatant was centrifuged at $40,000 \mathrm{X} g$ for 20 $\mathrm{min}$ and the pellet resuspended by gental homogenization in iced buffer and centrifuged again at $40,000 \times \mathrm{g}$ for $20 \mathrm{~min}$. This washed pellet was resuspended in the same buffer to a final membrane protein concentration of $1-2 \mathrm{mg} / \mathrm{ml}$, as determined by the method of Lowry et al. (14) with bovine serum albumin as standard. Samples were assayed for $\beta$-adrenergic receptor within several days after freezing in a dry ice-acetone bath and storage at $-80^{\circ} \mathrm{C}$. Catecholamine sensitive adenylate cyclase activity and $(-)-\left[{ }^{3} \mathrm{H}\right] \mathrm{DHA}$ binding were also determined in freshly prepared whole homogenates after filtration through four layers of gauze. Freezing or preparation of a washed membrane fraction decreased $\beta$-adrenergic stimulation of adenylate cyclase activity in adult rat lung fractions in preliminary experiments, whereas $\beta$-adrenergic receptors were entirely stable during preparation and storage.

Binding studies. Binding studies were performed in triplicate assays as previously described, in buffer containing $10 \mathrm{mM} \mathrm{MgCl}$, $50 \mathrm{mM}$ Tris- $\mathrm{HCl}(\mathrm{pH} 7.4)$ and $30-60 \mu \mathrm{g}$ of lung membrane protein (26-29). Specific binding at $5 \mathrm{nM}(-)-\left[{ }^{3} \mathrm{H}\right] \mathrm{DHA}$ was also determined in filtered crude lung homogenates to estimate total receptor number per lung. Higher protein concentrations were used in fetal and neonatal samples. ( - - $\left[{ }^{3} \mathrm{H}\right]$ DHA was diluted in buffer immediately before the assay, which was initiated by the addition of the membrane protein. After incubation at $30^{\circ} \mathrm{C}$ for $20 \mathrm{~min}$, the reaction was terminated by the addition of $4 \mathrm{ml}$ iced Mg-Tris buffer, followed by rapid filtration through Whatman glass fiber filters (Whatman, Inc., Clifton, NJ), which were washed with an additional $16 \mathrm{ml}$ iced buffer, dried and counted by standard liquid scintillation technique at $30 \%$ efficiency. Nonspecific binding was determined in triplicate assay containing $10^{-6} \mathrm{M}(-)$ alprenolol and was subtracted from total binding to determine specific binding. Nonspecific binding was identical whether obtained from displacement by antagonist or agonist $\left(10^{-4} \mathrm{M}(-)\right.$-isoproterenol).
Solutions of all agonists and antagonists were freshly prepared before each assay. Ascorbic acid or metabisulfite was added to protect agonists from oxidation during the incubation but it did not alter specific binding or agonist affinity in pilot experiments and was therefore omitted. Triplicate assays generally varied less than $10 \%$ for both total and nonspecific binding. The filter blank was less than $10 \%$ of total binding at the $K_{D}$ in samples from 28 day-old pups and accounted for most of the usual nonspecific binding at $(-)-\left[{ }^{3} \mathrm{H}\right] \mathrm{DHA}$ concentrations lower than the $\mathrm{K}_{\mathrm{D}}$. Equilibrium data were obtained at five or six $(-)-\left[{ }^{3} \mathrm{H}\right] \mathrm{DHA}$ concentrations $(0.2-5 \mathrm{nM})$, and the $\mathrm{K}_{\mathrm{D}}$ and $\mathrm{B}_{\max }$ were determined by the method of Scatchard. The linear regression correlation coefficient $(r)$ was in general greater than 0.90 for individual Scatchard plots in these studies. The statistical significance of differences in binding capacity or affinity among hypothyroid, T4-treated, and normal control rat lungs at each age were determined by a one way analysis of variance, corrected by the Neuman-Kuels test (22). To determine $\beta$-adrenergic subtypes in rat lung $( \pm)-\left[{ }^{125} I\right] H Y P$ binding was performed as previously described by Minneman et al. (16) in an assay volume of $250 \mu$ liters containing 10-20 $\mu \mathrm{g}$ membrane protein and $100 \mu \mathrm{M} \mathrm{GTP}$ or Gpp(NH)p in a buffer containing 10 $\mathrm{mM} \mathrm{MgCl} 2,50 \mathrm{mM}$ Tris- $\mathrm{HCl}\left(\mathrm{pH} \mathrm{7.4)}\right.$ at $37^{\circ} \mathrm{C}$ after $30 \mathrm{~min}$ incubation $(26,28)$. Nonspecific binding was identical whether determined in the presence of $10^{-6} \mathrm{M}(-)$ alprenolol or $10^{-5} \mathrm{M}$ $(-)$-isoproterenol and was less than $10 \%$ of total binding near the $K_{D}$ for $( \pm)-\left[{ }^{125} I\right] H Y P$. The use of $( \pm)-\left[{ }^{125} I\right] H Y P$ allowed increased assay sensitivity especially in the analysis of $\beta$-adrenergic receptor subtypes in lung from hypothyroid and young rat pups which contained fewer receptor sites.

The $( \pm)-\left[{ }^{125} I\right] H Y P$ concentration for these inhibition studies was maintained at $100 \mathrm{pM}$ which was the approximate $\mathrm{K}_{\mathrm{D}}$ for $( \pm)-\left[{ }^{125} I\right]$ HYP binding to rat lung determined from Scatchard analyses, which were linear. Hofstee plots of the competition experiments were analyzed by a reiterative program based on least squares fit for two components with distinct affinities using a Texas Instrument, Model TI-59 with printer, to resolve the curve arbitrarily into two lines; reiteration was continued until the $y$ intercepts changed less than $0.2 \%$. The $\mathrm{K}_{\mathrm{D}}$ 's for $\beta_{1^{-}}$and $\beta_{2^{-}}$ components were estimated from the slopes of the two lines generated from the Hofstee plots as described by Rosenthal (20).

Adenylate cyclase assay. Adenylate cyclase activity was determined in triplicate at $30^{\circ} \mathrm{C}$ in an established assay, which is a minor modification of the method of Salomon et al. $(21,28)$. The assay contained fresh crude lung homogenates, $80 \mathrm{mM}$ Tris- $\mathrm{HCl}$ (pH 7.4), $1 \mathrm{mM}\left[\alpha^{32} \mathrm{P}\right]$ ATP $(1-2 \mu \mathrm{Ci}), 4.2 \mathrm{mM} \mathrm{MgCl}, 1 \mathrm{mM}\left[{ }^{3} \mathrm{H}\right]$ cAMP $(0.003 \mu \mathrm{Ci})$, a creatine phosphokinase-ATP-regenerating system, $12.5 \mathrm{mM}$ sucrose, $0.05 \mathrm{mM}$ EGTA and added hormone. Column recoveries of $\left.{ }^{3} \mathrm{H}\right] \mathrm{cAMP}$ varied from $60-70 \%$. Theophylline $(5 \mathrm{mM})$ did not improve column recovery or adenylate cyclase activity and was therefore omitted. Basal and (-)-isoproterenol sensitive adenylate cyclase activities were linearly related to time $(0-20 \mathrm{~min})$ and protein under these conditions. GTP $\left(10^{-5} \mathrm{M}\right)$ or $\operatorname{Gpp}(\mathrm{NH}) \mathrm{p}\left(10^{-5} \mathrm{M}\right)$ enhanced basal activity but did not enhance catecholamine stimulation under these conditions and was therefore omitted. Variation of cAMP determination was less than $5 \%$ in replicate samples, and each data point represents the mean of at least four samples from each group determined in triplicate.

\section{RESULTS}

Rat pups nursed by dams on PTU (Group I-hypothyroid) manifested the characteristics of congenital hypothyroidism. Growth was nearly normal until 14 days of postnatal age in all groups. Thereafter, growth rate decreased, the day of eye opening and the appearance of hair growth was delayed in the hypothyroid group. These hypothyroid pups had characteristic short snouts and were both ataxic and less active than Group II (PTU + T4), and Group III (untreated control) pups. Serum thyroxine concentration was below detectability $(1 \mu \mathrm{g} / \mathrm{dl})$ in Group I pups at all ages tested. Somatic and lung growth were not altered in the 
Table 1. Effects of hypothyroidism and thyroxine treatment on lung growth characteristics ${ }^{1}$

\begin{tabular}{|c|c|c|c|c|c|c|c|}
\hline Group & Body wt (g) & Lung wt (g) & Lung protein (mg) & Lung DNA (mg) & $\begin{array}{c}\text { Protein/ } \\
\text { DNA (mg/ } \\
\text { mg) }\end{array}$ & T4 levels $(\mu \mathrm{g} / \mathrm{dl})$ & $\begin{array}{l}\text { Lung wt/ } \\
\text { Body wt }\end{array}$ \\
\hline \multicolumn{8}{|l|}{ I PTU } \\
\hline day $15 n=4$ & $26.2 \pm 2.9$ & $0.30 \pm 0.01^{\mathrm{b}}$ & $44.8 \pm 9.3^{\mathrm{ad}}$ & $2.49 \pm 0.18^{\mathrm{ac}}$ & 18.0 & $<1.0$ & 12.0 \\
\hline day $28 n=12$ & $34.8 \pm 5.6^{\mathrm{ac}}$ & $0.34 \pm 0.08^{\mathrm{ac}}$ & $\begin{array}{c}48.8 \pm 14.5^{\mathrm{ac}} \\
n=8\end{array}$ & $2.87 \pm 0.8^{c}$ & $\begin{array}{c}17.0 \\
n=8\end{array}$ & $\begin{array}{l}<1.0 \\
n=8\end{array}$ & 9.0 \\
\hline day $14-15 n=8$ & $24.0 \pm 3.7$ & $0.33 \pm 0.07$ & $\begin{array}{c}56.1 \pm 4.1 \\
n=4\end{array}$ & $\begin{array}{c}3.19 \pm 0.36 \\
n=4\end{array}$ & 17.6 & $\begin{array}{c}6.23 \pm 0.5 \\
n=3\end{array}$ & 13.9 \\
\hline day $28 n=8$ & $69.1 \pm 7.0$ & $0.58 \pm 0.1$ & $71.0 \pm 21.3$ & $4.02 \pm 0.39$ & 17.6 & $\begin{array}{c}1.7 \pm 0.3^{\mathrm{e}} \\
n=3\end{array}$ & 8.3 \\
\hline day $28 n=11$ & $74.8 \pm 5.4$ & $\begin{array}{c}0.52 \pm 0.10 \\
n=7\end{array}$ & $96.3 \pm 30.0$ & N.D. & N.D. & $\begin{array}{c}3.8 \pm 0.6 \\
n=4\end{array}$ & 6.8 \\
\hline
\end{tabular}

\footnotetext{
'Values represent the mean \pm S.D. Statistical differences were determined by a one way analysis of variance with a Neuman-Kuels correction.

${ }^{2}$ Group I $<$ Group III, ${ }^{\mathrm{a}} P<0.01,{ }^{\mathrm{b}} P<0.05$.

${ }^{3}$ Group I $<$ Group II, ${ }^{c} P<0.01,{ }^{\text {d }} P<0.05$, N.D. $=$ not determined.

${ }^{4}$ Group II $<$ Group III, ${ }^{e} P<0.05$.
}

hypothyroid pups on day 5 compared to both control groups and were only slightly less than in controls on day 15 . By day 28 these pups weighed significantly less than Group II and III pups (Table 1). Lung weight, DNA, and protein content were markedly decreased in Group I as compared to control animals at day $28, P$ $<0.01$. Lung DNA was also significantly decreased in Group I versus Group II at 28 days of age and lung DNA content did not increase significantly in hypothyroid animals after day 15 . This deficit of cellularity and mass was not recovered in hypothyroid animals up to 40 days of age. Whereas both DNA and protein content were decreased in the lungs from Group I hypothyroid animals as compared to controls on day 28 of age, the protein to DNA ratio of the lung was not altered by hypothyroidism at any of the ages studied.

$\beta$-Adrenergic receptor. Specific (-)- $\left[{ }^{3} \mathrm{H}\right] \mathrm{DHA}$ binding to adult rat lung membrane was reversible and saturable to a single class of sites, $K_{D}=0.74 \pm 0.17(\mathrm{nM}), B_{\max }=496 \pm 88 \mathrm{fmoles} \cdot \mathrm{mg}^{-1}$ protein, mean \pm S.D., $n=4$. Specific binding was time dependent, stereo-selective for (-)-isoproterenol and was not altered by 10 $\mu \mathrm{M}$ phentolamine. There was no specific binding to the filter under these conditions and nonspecific binding determined with $10^{-6} \mathrm{M}(-)$-alprenolol was identical to that with $10^{-4} \mathrm{M}(-)$ isoproterenol or $10^{-6} \mathrm{M}(-)$-propranolol. Specific binding increased linearly related to membrane protein concentrations and was complete at the lowest $(-)-\left[{ }^{3} \mathrm{H}\right] \mathrm{DHA}$ concentration before 20 $\min$ at $30^{\circ} \mathrm{C}$. The order of agonist potency competing for specific binding was $(-)$-isoproterenol $>(-)$-epinephrine $>(-)$-norepinephrine, characteristic of $\beta_{2}$-adrenergic receptor. Specific $(-)$ $\left[{ }^{3} \mathrm{H}\right] \mathrm{DHA}$ binding $\left(\mathrm{B}_{\max }\right)$ in lung membrane preparations increased progressively with advancing age from $46 \pm 7 \mathrm{fmoles} \cdot \mathrm{mg}^{-1}$ protein, $n=4$ (litters) on day 18 of gestation to $510 \pm 70, \mathrm{~m} \pm$ S.D., $n=4$ in the normal 28 day rat lung (Fig. 1). $\beta$-Receptor binding increased with age nearly independently of thyroid status until after 15 days of age in all groups (Table 2, Fig. 2 and 3). Binding characteristics, $B_{\max }$ and $K_{D}$, in Group II pups (T4 + PTU) were not different from Group III (untreated controls) at any of the ages studied.

By postnatal day $28, \beta$-adrenergic receptor binding capacity was significantly reduced in hypothyroid animals as compared to T4 treated controls, $294 \pm 57$ fmoles $\cdot \mathrm{mg}^{-1}$ protein, $n=9$ versus $489 \pm 82, n=8, P<0.01$ (Table 2). Affinity for $(-)-\left[{ }^{3} \mathrm{H}\right] \mathrm{DHA}$ did

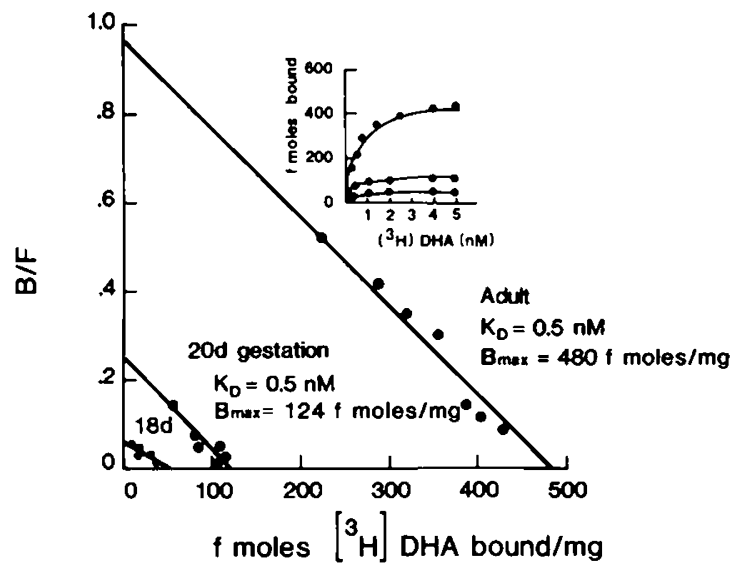

Fig. 1. Saturation curve and Scatchard analysis of (-)- $\left[{ }^{3} \mathrm{H}\right] \mathrm{DHA}$ binding to rat lung: days 18 and 20 of gestation and normal adult. Lungs from fetal animals were pooled from each litter, $n=4$, and $(-)-\left[{ }^{3} \mathrm{H}\right] \mathrm{DHA}$ binding determined in triplicate (total and nonspecific for each point). Curves are representative of experiments from at least three preparations at each age. $K_{D}$ and $B_{\max }$ were determined from the Scatchard plot. On day 18 of gestation the $K_{D}$ was $0.9 \mathrm{nM}$ and $B_{\max }=46$ femtomoles $\cdot \mathrm{mg}^{-1}$ protein.

not vary significantly with age or with thyroid status. The protein to DNA ratio was the same at 28 days in Groups I, II and III; therefore, the reduction of $\beta$-adrenergic receptors was significant whether assessed per $\mathrm{mg}$ protein or per lung cell. $\beta$-Adrenergic receptor binding in the crude lung homogenates confirmed the lower binding capacity observed in washed lung membranes from the hypothyroid pups on day 28 . Estimates of total numbers of $\beta$-adrenergic receptor sites per lung also demonstrated a greater deficit of $\beta$-adrenergic receptors than could be accounted for by loss of cellularity or protein content in the hypothyroid pups at 28 days (Tables 1 and 2 ).

In order to assess the reversibility of the reduction of $\beta$-adrenergic receptors in the hypothyroid animals, $\beta$-adrenergic receptors in lung membranes and crude homogenates were compared in animals maintained on PTU, which received saline diluent 
Table 2. Effects of hypothyroidism and thyroxine treatment on $\beta$-adrenergic receptor characteristics

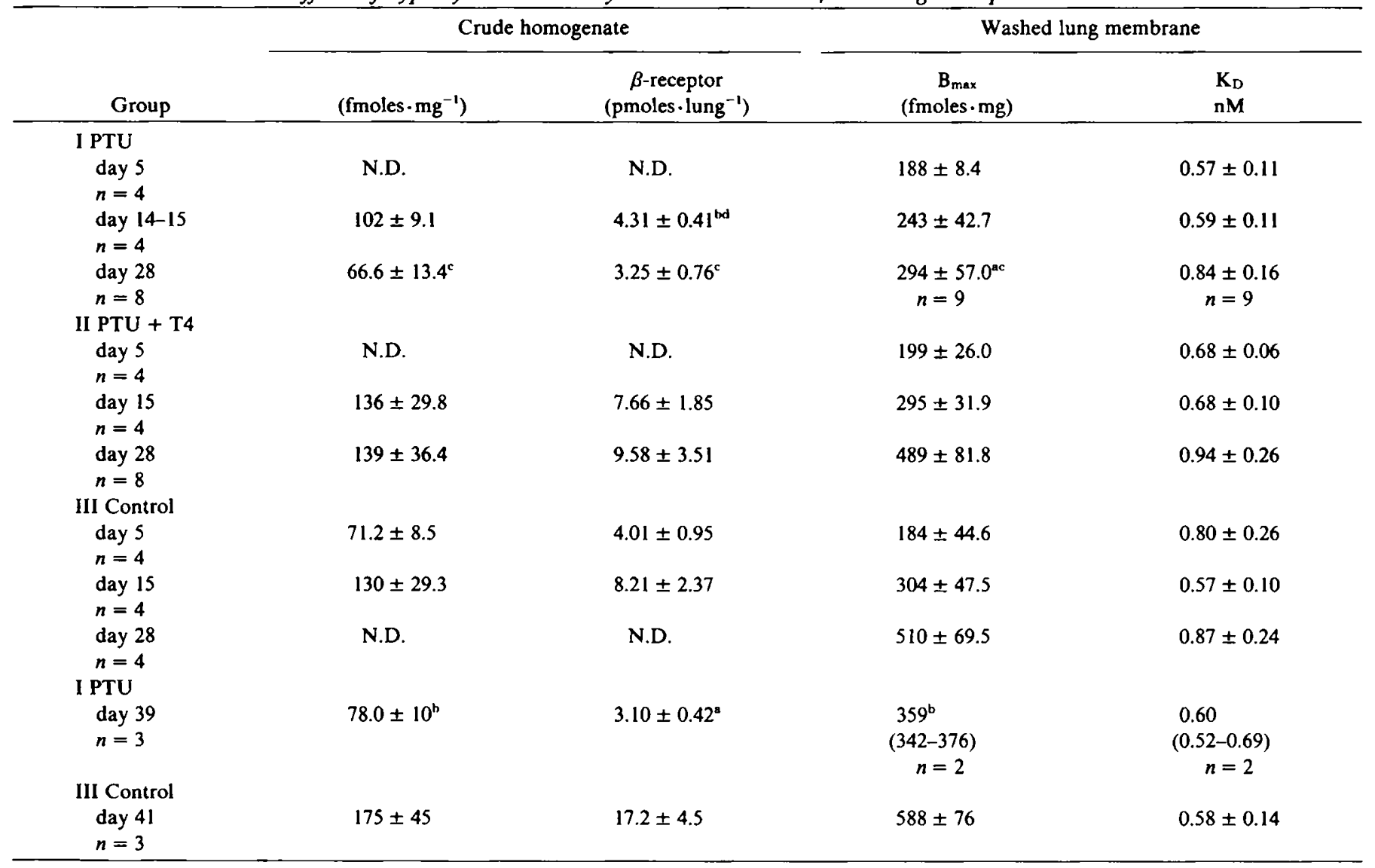

\footnotetext{
${ }^{1}$ Specific $(-)-\left[{ }^{3} \mathrm{H}\right] \mathrm{DHA}$ binding were determined in crude filtered homogenates in triplicate at $5.0 \mathrm{nM}(-)-\left[{ }^{3} \mathrm{H}\right] \mathrm{DHA}$. $\mathrm{B}_{\max }$ and $\mathrm{K}_{\mathrm{D}}$ for $(-)-\left[{ }^{3} \mathrm{H}\right] \mathrm{DHA}$ binding were determined by Scatchard analysis in the washed membrane fractions obtained for rat lungs at each age as described in the Methods.

${ }^{2}$ Group I $<$ Group III, ${ }^{\text {a }} P<0.01,{ }^{\text {b }} P<0.05$.

${ }^{3}$ Group I $<$ Group II, ${ }^{\mathrm{c}} P<0.01$, ${ }^{\mathrm{d}} P<0.05$.
}
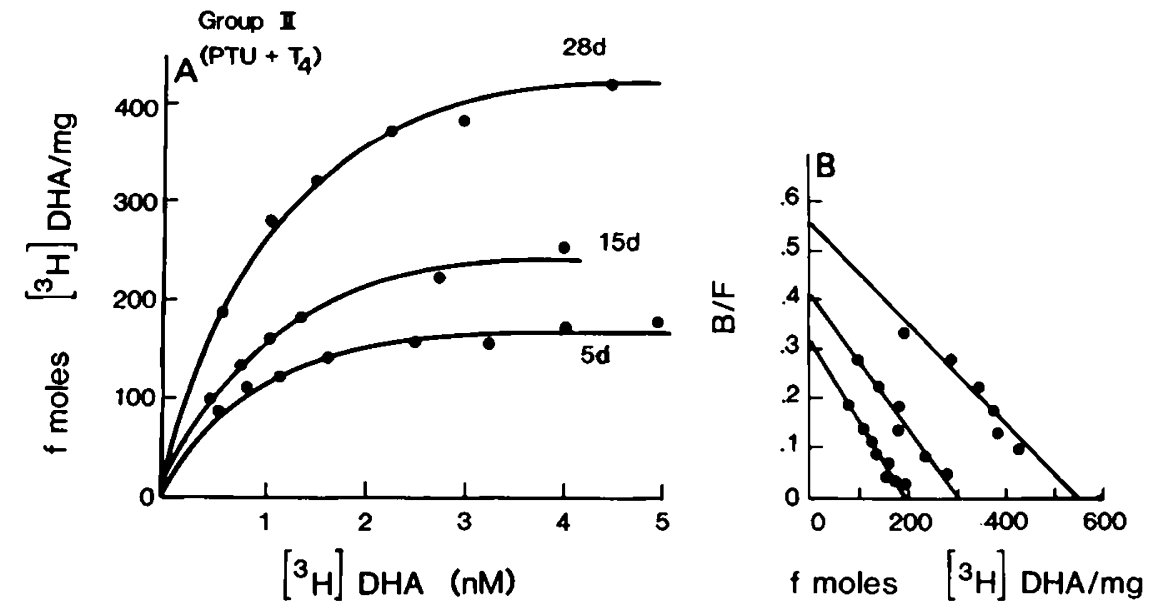

Fig. 2. Saturation curve (left hand panel) and Scatchard analysis (right hand panel) of (-)-[ $\left.{ }^{3} \mathrm{H}\right] \mathrm{DHA}$ binding to control lung from Group II (PTU + T4 treated) rat pups. Individual animals were treated daily with thyroxine as described in the methods and maintained on $0.05 \%$ PTU. Curves are representative of 4-8 separate experiments. Binding characteristics of untreated control rat lung, Group III, were similar to Group II controls at all ages studied, see Table 2.

only, and those maintained on PTU, which received $5 \mu \mathrm{g}$ T4 daily on postnatal days 25-27 and were sacrificed on day 28 (Table 3 ). Lung $\beta$-adrenergic receptors were significantly increased, $P<$ 0.01 , after T4 treatment, in great excess of the slight increase in protein and DNA content of the lungs (19\%) after T4 treatment in these pups.

In contrast to the reduction of $\beta$-adrenergic receptors in Group I hypothyroid animals on day 28 of age, the prolonged adminis- tration of PTU to mature adult animals did not significantly alter $\beta$-adrenergic receptor characteristics, $B_{\max }=450 \pm 40$ fmoles $\mathrm{mg}^{-1}, \mathrm{~K}_{\mathrm{D}}=0.80 \mathrm{nM}, n=4, \mathrm{~m} \pm \mathrm{S} . \mathrm{D} ., P>0.2$, as compared to age matched controls.

$\beta$-Adrenergic subtypes. Because of the marked cellular heterogeneity of lung homogenates, $\beta_{1}$ - and $\beta_{2}$-adrenergic subtypes were estimated with $( \pm)-\left[{ }^{125} I\right] H Y P$ binding to assess a possible selective loss of a particular receptor or cellular population in the 


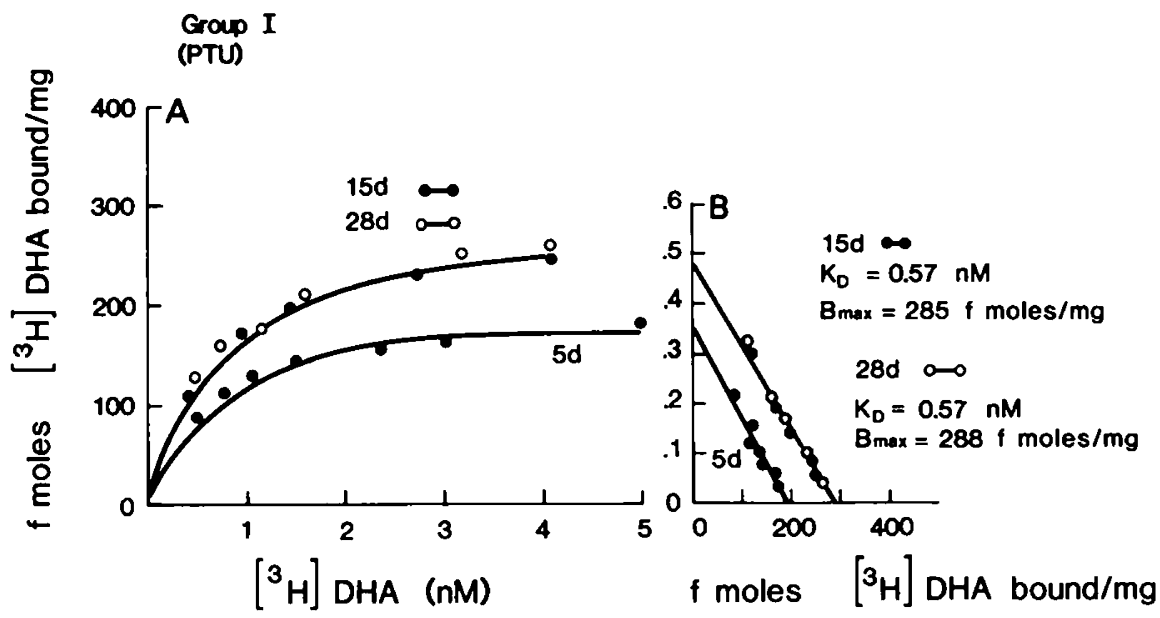

Fig. 3. Saturation curve (left hand panel) and Scatchard analysis (right hand panel) of $(-)-\left[{ }^{3} \mathrm{H}\right] \mathrm{DHA}$ binding in Group I (hypothyroid) rat lung. Curves are representative of 4-12 similar experiments with washed lung membrane from animals maintained on PTU on postnatal days 5,15 and 28. $K_{D}$ and $B_{\max }$ were determined from Scatchard plots and are listed on Table 2.

Table 3. Effect of thyroxine treatment of hypothyroid rats on days 25-27 on lung $\beta$-adrenergic receptors, protein, and DNA on day $28^{1}$

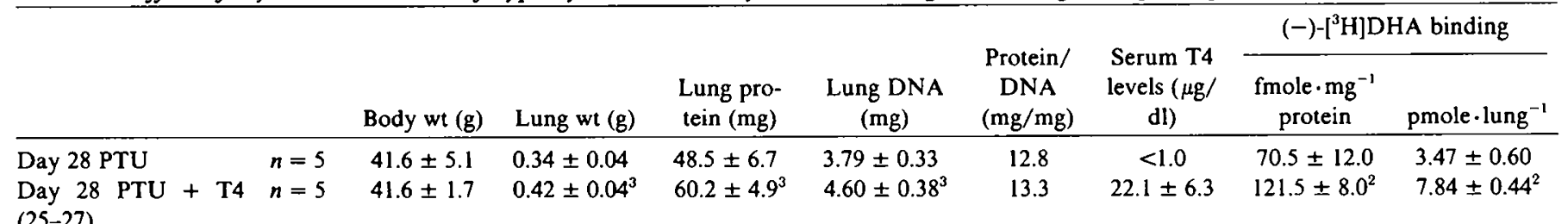

${ }^{1}$ Hypothyroid rats were injected (i.p.) with normal saline or $5.0 \mu \mathrm{g} \mathrm{T} 4$ on days $(25-27)$ before sacrifice on day 28 . (-)- $\left({ }^{3} \mathrm{H}\right) \mathrm{DHA}$ binding was performed in triplicate (specific and nonspecific) in the crude homogenate at $5 \mathrm{nM}(-)-\left({ }^{3} \mathrm{H}\right)$ DHA. Values represent mean \pm S.D., and the significance of differences between groups was determined by Student's $t$ test.

${ }^{2} P<0.01$.

${ }^{3} P<0.02$.
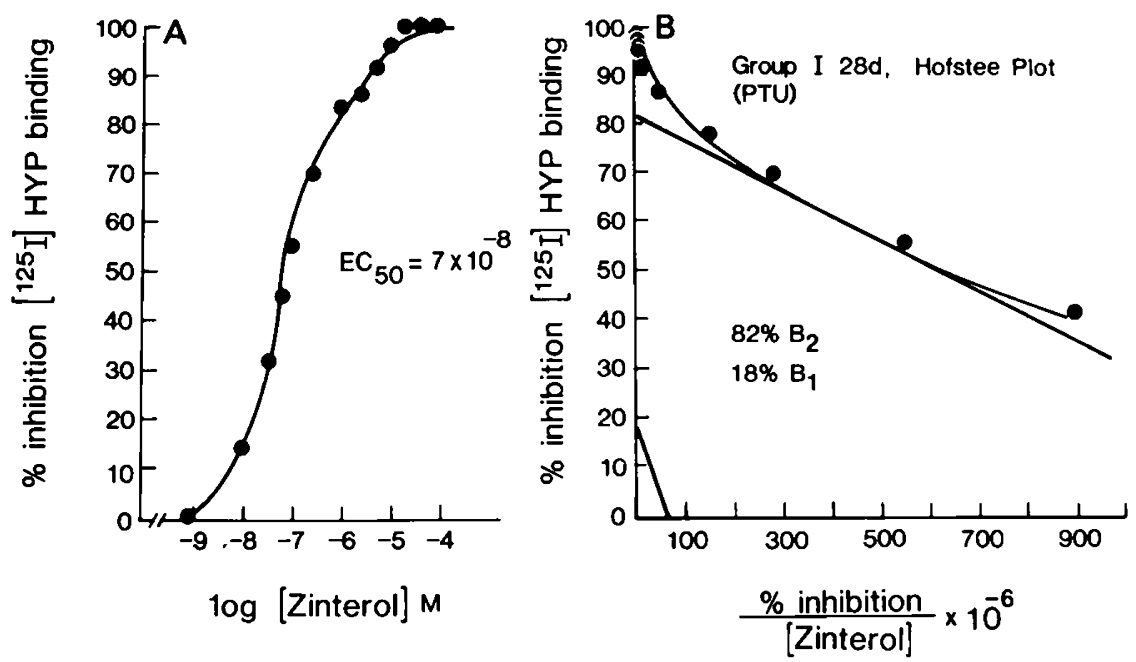

Fig. 4. $\beta$-Adrenergic subtypes in hypothyroid rat lung. Competition curve (left hand panel) and Hofstee plot (right hand panel) of the inhibition of specific $( \pm)-\left[{ }^{125} I\right] H Y P$ binding by $\beta_{2}$-selective agonist, zinterol, were performed with lung membrane from 28 day hypothyroid rat pups. $( \pm)-\left[{ }^{125} I\right] H Y P$ $(100 \mathrm{pM}), \mathrm{Gpp}(\mathrm{NH}) \mathrm{p}\left(10^{-4} \mathrm{M}\right)$ and membrane were incubated at $37^{\circ} \mathrm{C}$ for $30 \mathrm{~min}$ at 14 concentrations of zinterol. Binding was assessed in triplicate from two separate lung preparations.

hypothyroid pups. Specific ( \pm )-[ $\left.{ }^{125} \mathrm{I}\right] \mathrm{HYP}$ binding to lung membrane also displayed the properties of a $\beta$-adrenergic receptor, was saturable $\left(\mathrm{K}_{\mathrm{D}}=0.060 \mathrm{pM}\right)$, linearly related to protein, stereoselective for (-)-isomers, and time dependent, reaching maximal binding at lowest ligand concentrations within $50 \mathrm{~min}$ at $37^{\circ} \mathrm{C}$. Agonist potency of displacement of $( \pm)-\left[{ }^{125} \mathrm{I}\right] \mathrm{HYP}$ binding followed that of a $\beta_{2}$-adrenergic receptor and the number of sites $\left(B_{\max }\right)$ was similar whether defined by $(-)-\left[{ }^{3} \mathrm{H}\right] \mathrm{DHA}$ or $( \pm)-\left[{ }^{125} \mathrm{I}\right]$ HYP binding. Whereas the Hofstee analysis of competition curves of the nonselective agonists, (-)-isoproterenol, (-)-epinephrine and $(-)$-norepinephrine, were linear, the Hofstee analysis of competition curves of the $\beta_{2}$-selective agonist zinterol with the $\beta$ adrenergic antagonist $( \pm)-\left[{ }^{125} I\right] H Y P$, using rat lung membranes from Group I pups on day 28, were curvilinear (Fig. $4 a$ and $4 b$ ). Analysis of these curves demonstrates that the $\beta$-adrenergic receptor subtypes were present in approximate ratios of $80 \% \beta_{2}$ to $20 \%$ $\beta_{1}$-adrenergic sites in lung membranes from the hypothyroid and normal rat pups. 
Table 4. Adenylate Cyclase Activity in Crude Lung Homogenates ${ }^{1}$ c-AMP produced (pmoles $\cdot \mathrm{mg}^{-1} \cdot \mathrm{min}^{-1}$ )

\begin{tabular}{|c|c|c|c|c|}
\hline & & Basal & $\begin{array}{c}(-) \text {-Isoproter- } \\
\text { enol }\end{array}$ & $\mathrm{NaF}$ \\
\hline Group I PTU & $n=8$ & $30.8 \pm 8.0$ & $44.0 \pm 10.7^{b}$ & $79.1 \pm 24.5^{\mathrm{s}}$ \\
\hline Group II PTU + T4 & $n=4$ & $41.2 \pm 10.1$ & $62.3 \pm 15.4$ & $104.5 \pm 25.9$ \\
\hline Group III Control & $n=7$ & $46.3 \pm 14.4$ & $78.9 \pm 26.4$ & $151.3 \pm 45$ \\
\hline Adult PTU (A) & $n=4$ & $20.2 \pm 2.0$ & $35.8 \pm 3.5$ & $99.7 \pm 7.8^{c}$ \\
\hline Adult control (B) & $n=4$ & $25.4 \pm 6.7$ & $43.1 \pm 10.3$ & $123.0 \pm 15.4$ \\
\hline
\end{tabular}

${ }^{1}$ Adenylate cyclase activity was determined in crude filtered lung homogenates obtained from 28-day-old rats from each group and in adult rats maintained on water or PTU. Activity was determined in the presence or absence of $5 \times 10^{-7} \mathrm{M}(-)$-isoproterenol or $10 \mathrm{mM} \mathrm{NaF}$ at $30^{\circ} \mathrm{C}$ after incubation for $15 \mathrm{~min}$. Significant differences between groups were determined by a one way analysis of variance using the Neuman-Kuels correction. There were no significant differences between Groups II and III on day 28. The significance of the differences between two groups of adult rats was determined by Student's $t$ test. Stimulation of basal activity by $(-)$-isoproterenol was significant as assessed by paired $t$ test in all groups, $P<0.01$.

${ }^{2}$ Group I $<$ III, ${ }^{\text {a }} P<0.01,{ }^{b} P<0.05$.

${ }^{3}$ Group $\mathrm{A}<\mathrm{B},{ }^{\mathrm{c}} \mathrm{P}<0.05$.

In preliminary experiments GTP and $\mathrm{Gpp}(\mathrm{NH}) \mathrm{p}\left(10^{-4} \mathrm{M}\right)$ were found to decrease agonist affinity for $( \pm)-\left[{ }^{125} \mathrm{I}\right] \mathrm{HYP}$ binding to rat lung membranes and to increase the Hill coefficient from 0.6 to approximately 1.0 . In the presence of $\mathrm{Gpp}(\mathrm{NH}) \mathrm{p}$, agonists also competed for $( \pm)-\left[{ }^{125} \mathrm{I}\right] \mathrm{HYP}$ binding in the order of potency of a $\beta_{2}$-adrenergic site, and the shift in agonist potency in the presence of $\mathrm{Gpp}(\mathrm{NH}) \mathrm{p}$ was identical in fetal and adult samples (not shown).

Adenylate cyclase activity. Adenylate cyclase activity in fresh crude rat lung homogenate was sensitive to $(-)$-isoproterenol $(5$ $\left.\times 10^{-7} \mathrm{M}\right)$, NaF $(10 \mathrm{mM})$, GTP $\left(10^{-5} \mathrm{M}\right)$, Gpp(NH)p $\left(10^{-5} \mathrm{M}\right)$ and prostaglandin $\mathrm{E}_{1}\left(2.5 \times 10^{-5} \mathrm{M}\right)$ (not shown). Significant activation by (-)-isoproterenol $\left(5 \times 10^{-7} \mathrm{M}\right)$ was observed in all groups on day $28, P<0.01$. (-)-Isoproterenol and $\mathrm{NaF}$ stimulated activities were slightly but significantly decreased in homogenates from Group I hypothyroid pups on day 28 , as compared to Group III control animals (Table 4). Likewise, (-)-isoproterenol stimulated activity was lower in Group I than II; however, this difference did not reach statistical significance. Basal activity and (-)-isoproterenol sensitive adenylate cyclase activity were not altered in adult rats maintained on PTU for 6 wk (after reaching maturity) as compared to normal weight matched controls (Groups $A$ and B, Table 4).

\section{DISCUSSION}

The present study demonstrates the effect of hypothyroidism and thyroxine on the postnatal development of $\beta$-adrenergic receptors in the rat lung. $\beta$-Adrenergic receptors increased until postnatal day 15 almost independently of thyroid status while much of the marked increase in $\beta$-adrenergic receptor capacity $\left(B_{\max }\right)$, which occurs between days 15 and 28 in the developing rat lung, is absent in hypothyroid pups. This timing corresponds to the known increases in thyroid activity, TSH, T3 and T4 levels in the rat (8) and strongly supports the role of thyroid hormone or other factors which are thyroid dependent in the normal physiologic maturation of the $\beta$-adrenergic receptors in the lung. Second, the effect of hypothyroidism of lung $\beta$-adrenergic receptors was readily reversed by treatment of 25 -day-old hypothyroid rats with thyroxine for 3 days, increasing $\beta$-adrenergic receptors independently of lung protein or DNA content on day 28 of postnatal life.

Although it is generally recognized that thyroid hormone plays an important role in the growth and differentiation of the central nervous system, its possible role in these processes in the lung are less studied. Growth of the mammalian lung occurs both by hyperplasia and by hypertrophy, cell division being nearly com- plete in the rat lung by postnatal day $28(24,31)$. In the present study $\beta$-adrenergic receptors increased almost independently of the thyroid hormone from day 18 of gestation to postnatal day 15 . However, the increase in $\beta$-adrenergic receptors thereafter was entirely dependent upon thyroid activity. The present study also demonstrates an important role of the thyroid hormone or thyroid dependent factors in the postnatal growth of the lung. Lung DNA and protein content were not greatly altered by hypothyroidism until after postnatal day 15 . Thereafter, both lung growth and general somatic growth were also highly affected in the hypothyroid pups. Lung weight, DNA and protein were markedly decreased in hypothyroid pups by 28 days of age and did not recover even after 40 days of age in these animals, demonstrating a final deficit in cell number of approximately one-half. However, it is unclear from the present study whether lung growth in the hypothyroid pups might recover if assessed after 40 days of age. These findings are in agreement with studies of 25-day-old hypothyroid rats, which demonstrated a decrease in lung weight and DNA content as compared to controls (3). Although total lung protein, DNA and weight were decreased to 59,68 and $71 \%$ of control values (respectively) in 28 day hypothyroid pups, total $\beta$-adrenergic receptor content in hypothyroid rat lung at this age was reduced to $33 \%$ of normal concentrations. The ratio of cell protein to DNA content did not change with advancing age or with thyroid status in any of the groups. Thus the changes in $\beta$ adrenergic receptor, assessed per mg protein, are equivalent to those expressed per mg DNA or per cell.

It is unclear from the present study whether specific cell types are involved in the reduction of $\beta$-adrenergic receptors in lung membranes from the hypothyroid rats. Beta ${ }_{1}-$ and $\beta_{2}$-adrenergic receptor sites $\left(80 \% \beta_{2}: 20 \% \beta_{1}\right)$ were identified in the present study in both euthyroid and hypothyroid animals, in agreement with previous studies $(16,26)$. Thus the thyroid hormone dependent increase in $\beta$-adrenergic receptors affects both $\beta_{1}$ - and $\beta_{2}$-adrenergic subtypes equally and the loss in receptor sites is not likely to be accounted for by a loss of a single cell type containing $\beta$ adrenergic sites. Because the lung contains up to 40 different cell types, it is unclear which cells contain the $\beta$-receptor and in what proportion specific cell types might be altered or lost in the hypothyroid rat lung. There is evidence that the alveolar type II cell is thyroid hormone responsive, containing triiodothyronine (T3) receptors and there is some evidence that these receptors mediate surfactant metabolism and release $(7,12,13,18)$. Fetal rabbits treated with $\mathrm{T} 4$ or its analog, DIMIT, in utero have accelerated lung maturation by morphologic and biochemical criteria $(1,32)$. Thyroxine added to lung explants in vitro enhances the morphologic maturation of type II epithelial cells and T3 receptors have been demonstrated in a clonally derived rat type II cell line supporting the role of thyroid hormone in the metabolism of these pulmonary epithelial cells $(12,22)$. Studies of surfactant synthesis in adult rats of varying thyroid hormone status have resulted in conflicting observations $(15,18)$. Thyroxine increased cell size, the numbers of lamellar bodies, and surfactant release of the type II cells into alveolar washes from mature rat lung (18); however, similar changes in surfactant composition and content were not observed in a subsequent study by Mason et al. (15). Similarly, in the present study pulmonary $\beta$-adrenergic receptors and adenylate cyclase were not altered in mature rats made hypothyroid with PTU. Pulmonary smooth muscle cells are catecholamine-responsive but there is little evidence at present of an interrelationship between smooth muscle tone and thyroid status; a clear role of thyroid hormones in catecholamine mediation of smooth muscle tone in the lung has not been demonstrated to our knowledge. The contribution of $\beta$-adrenergic sites by alveolar macrophages is not likely to be large; alveolar macrophages obtained from alveolar washings from the adult rat contain few $\left(<30\right.$ fmoles $\left.\cdot \mathrm{mg}^{-1}\right) \beta$-adrenergic binding sites as compared to lung parenchyma (unpublished observations). Whether thyroid dependent increases in $\beta$-adrenergic receptors are a direct effect of lung triiodothyronine (T3) or are related to other thyroid dependent hormones which then affect the development of the lung remains to be evaluated in in vitro systems. 
In the present study, the numbers of $\beta$-adrenergic receptors are not directly correlated with serum T4 concentrations. Adult animals made hypothyroid after maturity had normal lung $\beta$-adrenergic receptors in spite of undetectable serum $\mathrm{T} 4$, and increases in $\beta$-adrenergic receptors occurred in spite of the low serum T4 concentration in the fetal and neonatal rat until day 15 of age. The low serum T4 concentration in Group II animals (T4 and PTU) at 28 days may relate to the treatment schedule in which this last $\mathrm{T} 4$ dose was administered $24 \mathrm{~h}$ before sacrifice. In spite of the low T4 level in Group II animals on day 28, they had no signs of hypothyroidism, grew normally as shown by Hamburgh et al. (11) and had a normal increase in $\beta$-adrenergic receptor sites. These findings support the hypothesis that the maturation of pulmonary $\beta$-adrenergic receptors is dependent upon thyroid hormone or factors influenced by thyroid status rather than a direct modulation of the receptor sites (at all ages) by prevailing serum thyroid hormone concentrations. The ontogeny of serum T4 concentrations described in the present study is in close agreement with previous work demonstrating increased activity occurring during the second and third wk of life in the rat (8). Finally, changes in nutritional status or other growth factors have also been observed in thyroid deficiency and might also alter the growth and maturation of the lung in the hypothyroid animals observed in the present study.

Catecholamine sensitive adenylate cyclase activity in crude lung homogenates was decreased in hypothyroid as compared to euthyroid controls at 28 days of age. It is not likely, however, that this is related directly to the numbers of $\beta$-receptors since basal and $\mathrm{NaF}$ activation were also decreased in the hypothyroid animals. These changes in catalytic activity and the developmental changes in basal adenylate cyclase activity $(26,28)$ complicate the interpretation of humoral sensitivity in lung homogenates and slices in these and several other studies, including those from this laboratory $(2,17,26,27)$. Thus the heterogeneity of the cells and the poor coupling efficiency generally observed in lung homogenates warrants caution in interpreting these results; more detailed studies of the interrelationships among receptor, guanine nucleotide dependent factors and the catalytic subunit in homogeneous pulmonary cells from these animals will be required in order to determine the relationship between the developmental increase of thyroid dependent $\beta$-adrenergic receptors and cAMP formation in the lung.

The timing of the thyroid dependent maturation of the $\beta$ adrenergic system in the lung correlates with other known thyroid hormone dependent changes in the rat $(3,10,11)$. Because the timing of increased thyroid activity varies greatly among species (earlier in postnatal period in the human) it is also possible that the thyroid dependent maturation of $\beta$-adrenergic receptors in the lung may occur earlier in perinatal life in the human than in the rat. Whether the thyroid dependent increase of lung $\beta$-adrenergic receptors plays a significant role in perinatal and postnatal pulmonary function remains to be determined. The present study and others support the hypothesis that thyroid hormone mediates various aspects of pulmonary maturation at distinct times during development $(1,9,23,32)$.

\section{REFERENCES AND NOTES}

I. Ballard, P. L., Benson, B. J., Brehier, A., Carter, J. P., Kriz, B. M., and Jorgensen, E. C.: Transplacental stimulation of lung development in the fetal rabbit by 3,5-dimethyl-3'-isopropyl-1-thyronine. J. Clin. Invest., 65: 1407 (1980).

2. Barrett, C. T., Sevanian, A., and Kaplan, S. A.: Adenylate cyclase activity in immature rabbit lung. Pediatr. Res.. 8: 244 (1974).

3. Brasel, J. A. and Winick, A.: Differential cellular growth in the organs of hypothyroid rats. Growth, 34: 197 (1970)

4. Burton, K.: A study of the conditions and mechanisms of the diphenylamine reaction for the colorimetric estimation of deoxyribonucleic acid. Biochem. J., 62: 315 (1956).

5. Cheng, J. B., Goldfien, A., Ballard, P. L., and Roberts, J. M.: Glucocorticoids increase pulmonary $\beta$-adrenergic receptors in fetal rabbit. Endocrinology, 107 ; $1646(1980)$.

6. Cuestas, R. A., Lindall, A., and Engel, R. R.: Low thyroid hormone and respiratory distress syndrome of the newborn. Studies on cord blood. N. Engl. J. Med., 295: 298 (1976).

7. Dobbs, L. G. and Mason, R. J.: Pulmonary alveolar type II cells isolated from rats: release of phosphatidylcholine in response to $\beta$-adrenergic stimulation. $J$. Clin. Invest., 63: 378 (1979).

8. Dussault, J. H. and Labrie, F.: Development of the hypothalamic pituitarythyroid axis in the neonatal rat. Endocrinology, 978: 1321 (1975).

9. Erenberg. A., Omari, K., Menkes, J. H., Oh, W., and Fisher, D. A.: Growth and development of the thyroidectomized ovine fetus. Pediatr. Res., 8: 783 (1974)

10. Greenberg, A. H., Najjar, S., and Blizzard, R. M.: Effects of thyroid hormone on growth, differentiation and development. In: Handbook of Physiology and Endocrinology, Thyroid. American Physiologic Society, p. 37 (Williams and Wilkins Co., Baltimore, MD Vol. III, 1972).

11. Hamburgh, M., Lynn, E., and Weiss, E. P.: Analysis of the influence of thyroid hormone on prenatal and postnatal maturation of the rat. Anat. Rec., 150: 157 (1974).

12. Hitchcock, K. R.: Hormone and the lung. Immunohistochemical localization of thyroid hormone binding in type II pulmonary epithelial cells clonally derived from adult rat cells. Anat. Rec., 195: 611 (1979).

13. Lindenberg, J. A., Brehier, A., and Ballard, P. L.: Triiodothyronine nuclear binding in fetal and adult rabbit lung and cultured lung cells. Endocrinology 103: 1725 (1978).

14. Lowry, O. H., Rosebrough, N. J., Farr, A. L., and Randall, R. J.: Protein measurement with the folin phenol reagent. J. Biol. Chem., 193: 265 (1951)

15. Mason, R. J., Manganiello, V., and Vaugh, M.: Effect of thyroxine on the disaturate lecithin content of lung. Amer. Rev. Resp. Dis., 106: 767 (1972).

16. Minneman, K. P., Hegstrand, L. R., and Molinoff, P. B.: Simultaneous determination of Beta-1 and Beta-2-adrenergic receptors in tissues containing both receptor subtypes. Mol. Pharmacol., 16: 34 (1979).

17. Palmer, G. C.: Cyclic 3'-5'-adenosine monophosphate response in the rabbi lung-adult properties and development. Biochem. Pharmacol., 2J: 2907 (1972)

18. Redding, R. A., Douglas, W., and Stein, M.: Thyroid hormone influence upon lung surfactant metabolism. Science, 175: 994 (1972).

19. Redding, R. R. and Pereira, C.: Thyroid function in respiratory distress syndrome (RDS) of the newborn. Pediatrics. 54: 423 (1974).

20. Rosenthal, H. E.: A graphic method for the determination and presentation of binding parameters in a complex system. Anal. Biochem., 20: 525 (1967).

21. Salomon, Y., Londos, C., and Rodbell, M.: A highly sensitive adenylate cyclase assay. Anal. Biochem., 58: 541 (1974).

22. Schefler, W. C.: Statistics for the Biological Sciences, 2nd Edition. pp 121-144 (Additon-Wesley Publishing Co., Reading, MA, 1979.)

23. Smith, B. and Torday, J. S.: Factors affecting synthesis by fetal lung cells in culture. Pediatr. Res., 8: 848 (1974).

24. Thurlbeck, W. M.: Postnatal growth and development of the lung. Amer. Rev. Resp. Dis., 111: 803 (1975).

25. Tsai, J. S. and Chen, A.: L-triiodothyronine increases the level of $\beta$-adrenergic receptor in cultured myocardial cells. Nature, 275: 138 (1978).

26. Whitsett, J. A., Darovec-Beckerman, C., Manton, M., and Adams, K.: $\beta$-Adrenergic receptors and catecholamine sensitive adenylate cyclase in the developing rat lung. Life Sci., 28: 339 (1981).

27. Whitsett, J. A., Darovec-Beckerman, C., Adams, K., Pollinger, J., and Needelman, $H$.: Thyroid hormone mediates the development of pulmonary $\beta$-adrenergic receptors in the rat. Biochem. Biophys. Res. Commun., 97: 913 (1980).

28. Whitsett, J. A., Manton, M. A., Darovec-Beckerman, C., Adams, K., and Moore. J. J.: Ontogeny of $\beta$-adrenergic receptors in rabbit lung. Am. J. Physiol., 240: E351 (1981).

29. Whitsett, J. A., Johnson, C. L., Darovec-Beckerman, C., and Costello, M.: $\beta$ Adrenergic receptors and catecholamine sensitive adenylate cyclase of the human placenta. J. Clin. Endocrinol. Metab., 50: 27 (1980).

30. Williams, L. T., Lefkowitz, L. K., Watanabe, A. M., Hathaway, D. R., and Besch H. R., Jr.: Thyroid hormone regulation of $\beta$-adrenergic receptor number. J. Biol. Chem., 252: 2787 (1977).

31. Winick, M. and Noble, A.: Quantitative changes in DNA, RNA and protein during neonatal and postnatal growth in the rat. Dev. Biol., 12: 451 (1965).

32. Wu, B., Kikkawa, Y., Orzalesi, M. M., Motoyama, E. K., Kaibera, M., Zigas, C. J., and Cook, C. D.: The effects of thyroxine on the maturation of fetal rabbit lungs. Biol. Neonate, 22: 161 (1973).

33. Requests for reprints should be addressed to: Dr. Jeffrey A. Whitsett, Newborn Division of Pediatrics, University of Cincinnati College of Medicine, 231 Bethesda Avenue, Cincinnati, $\mathrm{OH} 45267$.

34. This research was supported in part by NICHD Grant No. 11725 and the Children's Hospital Research Foundation, Cincinnati. Ohio.

35. Received for publication May 1, 1981.

36. Accepted for publication September 23, 1981. 